\title{
$\begin{array}{lllllllllllllllll}\mathbf{R} & \mathbf{O} & \mathrm{Z} & \mathbf{P} & \mathbf{R} & \mathbf{A} & \mathbf{W} & \mathbf{Y} & \text { I } & \text { A } & \mathbf{R} & \mathbf{T} & \mathbf{Y} & \mathrm{K} & \mathbf{U} & \mathbf{L} & \mathbf{Y}\end{array}$
}

Ius Matrimoniale 32 (2021) nr 1

ISSN 1429-3803; e-ISSN 2353-8120

DOI: http://doi.org/10.21697/im.2021.32.1.01
Artykuł jest udostępniany na zasadach licencji Creative Commons (CC BY-ND 4.0 Międzynarodowe) https://creativecommons.org/licenses/by-nd/4.0/deed.pl

open 2 access (c) $\bigodot_{\mathrm{BY}} \bigodot_{\mathrm{ND}}$

\section{Orzeczenie w sprawie nullitatis matrimonii - i co dalej? Franciszek do Roty Rzymskiej z okazji inauguracji nowego Roku Sądowego 2021}

\author{
The sentence on nullitatis matrimonii - and what next? Francis to the Roman
}

Rota on the occasion of the inauguration of the new Judicial Year 2021

\author{
ks. Wojciech Góralski \\ Wydział Prawa Kanonicznego UKSW \\ ORCID: 0000-0001-6548-4120 \\ e-mail: w.goralski@uksw.edu.pl
}

Streszczenie: 29 stycznia 2021 roku, w czasie uroczystej inauguracji kolejnego Roku Sądowego w Rocie Rzymskiej, Papież Franciszek, w czasie audiencji dla audytorów i innych urzędników rotalnych, wygłosił przemówienie. Papież zaapelował do sędziów, aby nie zapominali, że integralne dobro osoby wymaga od nich, aby nie pozostawali obojętni wobec przykrych konsekwencji, jakie może spowodować orzeczenie o nieważności małżeństwa. Ojciec Święty postawił pytanie: Co się stanie z dziećmi i małżonkiem, który nie akceptuje nieważności małżeństwa? Jest bardzo pilne, aby biskupi, sędziowie, proboszczowie i inni duszpasterze dołożyli wszelkich starań, aby pomóc opuszczonym małżonkom i ich dzieciom. Na zakończenie przemówienia Franciszek wyraził uznanie dla pracy Roty Rzymskiej i podziękował emerytowanemu dziekanowi za pełnienie posługi z pełnym poświęceniem.

Słowa kluczowe: Franciszek, Rota Rzymska, małżeństwo, wyrok, nieważność małżeństwa, małżonkowie, dzieci, troska duszpasterska

Abstract: On January 29, 2021, on the solemn inauguration of the next Judicial Year of the Roman Rota, Pope Francis received in audience the judges and other employees of this Apostolic Tribunal. The Pope appealed to the judges not to forget that the integral good of the person requires them not to remain indifferent in the face of the unpleasant consequences that may be caused by a sentence on nullity of marriage. The Holy Father asks: What will happen to the children and the spouse who does not accept the nullity of the marriage? It is very urgent that bishops, judges, parish priests and other pastors do their best to help abandoned spouses and their children.

At the end of the speech, Francis expressed his appreciation for the work of the Roman Rota and thanked the retiring dean for sacrifice of the service. 
Keywords: Francis, Roman Rota, marriage, sentence, nullity of marriage, spouses, children, pastoral care

Treść: Wstęp. 1. Właściwe rozumienie bonum familiae. 2. Stwierdzenie nieważności małżeństwa źródłem pokoju, lecz niekiedy również źródłem niepokoju. 3. Otwarcie sędziów na horyzonty duszpasterstwa rodzin. 4. Wyobraźnia miłości w obliczu rodzinnych tragedii. 5. Uznanie dla Trybunału Roty Rzymskiej. 6. Podziękowanie dla dziekana Pio Vito Pinto. Uwagi końcowe.

\section{Wstęp}

29 stycznia 2021 roku, w dniu uroczystej inauguracji kolejnego Roku Sądowego Roty Rzymskiej, w Sali Klementyńskiej Pałacu Apostolskiego, papież Franciszek przyjął na audiencji prałatów-audytorów wymienionego Trybunału Apostolskiego oraz pozostałych jego pracowników, adwokatów, biegłych oraz studentów Studium Rotalnego.

Po przemówieniu Mons. Pio Vito Pinto, dziekana Roty Rzymskiej, swoją alokucję wygłosił papież Franciszek, poruszając w niej kilka kwestii związanych z procesem o stwierdzenie nieważności małżeństwa.

Wyrażając na wstępie radość ze spotkania i pozdrawiając serdecznie jego uczestników, a także dziękując dziekanowi za jego słowa, Ojciec Święty przeprasza, że przemawia, siedząc, dokucza mu bowiem rwa kulszowa ${ }^{1}$.

\section{Właściwe rozumienie bonum familiae}

W nawiązaniu do swojej analogicznej alokucji z roku $2020^{2}$, a w szczególności do tematu dotyczącego - w znacznej mierze - współczesnych

1 Discorso del Santo Padre Francesco agli Officiali del Tribunale della Rota Romana, per l'inaugurazione dell'Anno Giudiziario (29.01.2021), akapity 1-3, http://www.vatican.va/content/francesco/it/speeches/2021/january/documents/ papa-francesco_20210129_rota-romana (dostęp 31.01.2021).

${ }^{2}$ Por. W. Góralski, Małżonkowie chrześcijańscy na wzór Akwili i Pryscylli darem Bożym i potrzeba Kościoła. Z przemówienia Franciszka do Roty Rzymskiej z 25 stycznia 2020 roku, Prawo Kanoniczne (w druku). 
decyzji rotalnych: ukazujących z jednej strony brak wiary, która nie oświeca, tak jak powinna, wspólnotę małżeńską (trzykrotnie poruszał publicznie ten wątek Benedykt XVI ${ }^{3}$, z drugiej zaś podstawowe aspekty tej wspólnoty, które poza związkiem między mężczyzną i kobietą obejmują narodziny i dar dzieci oraz ich wzrost, Franciszek wyraża przekonanie, że orzecznictwo Roty Rzymskiej, w zgodności z Magisterium papieskim, ukazało hierarchię dóbr małżeństwa wyjaśniając, że postać dobra rodziny (bonum falmiliae) nie odnosi się do tytułów nieważności, mimo że w przeszłości otworzyła się pewna „furtka” w stosunku do hipotetycznego tytułu nieważności związanego z dobrem rodziny ${ }^{4}$. Taka możliwość została odpowiednio „zamknięta”, wzmacniając w ten sposób postać teologiczną jako skutek małżeństwa zapowiedziany przez Stwórcę. Ze swojej strony, stwierdza Ojciec Święty, „poleciłem, by bonum familiae nie było postrzegane w sposób negatywny, tak jakby można je było uznać za jeden $z$ tytułów nieważności. $W$ istocie, jest ono zawsze i mimo wszystko, błogosławionym owocem paktu małżeńskiego; nie można go w całości «wygasić» wraz ze stwierdzeniem nieważności, gdyż bycie rodziną nie może być traktowane jako dobro zawieszone, jest bowiem owocem planu Bożego, przynajmniej w odniesieniu do zrodzonego potomstwa. Małżonkowie z dziećmi otrzymanymi od Boga są ową nową rzeczywistością, którą nazywamy rodziną"5.

3 Por. Benedictus XVI, Discorso alla Rota Romana del 26 gennaio 2013, AAS 105 (2013), s. 168-172; Tenże, Discorso al Clero della diocesi di Aosta del 25 luglio 2005, AAS (2005), s. 168-172; TenżE, Discorso per l'apertura del Sinodo dei Vescovi del 7 ottobre 2012, http://www.vatican/content/benedict-XVI/it/homilis/29121007_ apertura-sinodo-html (dostęp 2.02.2021).

4 Por. J.M. Serrano Ruiz, L'esclusione della prole e la sua assolutezza: il problema della paternità responsabile, w: Prole e matrimonio canonico, Città del Vaticano 2003, s. 159-160; Tenże, Familia e pluralismo religioso: Note introduttive. Presupposti e prospettive nel sistema Canonico, w: Tutela della famiglia e diritto dei minori nel Codice di Diritto Canonico, Città del Vaticano 2000, s. 97-98; TenżE, Il „bonum coniugum" e la dottrina tradizionale dei „bona matrimonii”, w: Il „bonum coniugum” nel matrimonio canonico, Città del Vaticano 1996, s. 137-156.

5 „Da parte mia, non ho mancato di raccomandare che il bonum familiae non sia visto in modo negativo, quasi possa ritenersi come uno dei capi di nullità. Esso, 


\section{Stwierdzenie nieważności małżeństwa źródłem pokoju, lecz niekiedy również źródłem niepokoju}

W przypadku małżeństwa, kontynuuje Papież, które zostało prawomocnie uznane za nieważne, strona, która nie jest skłonna zaakceptować tego postanowienia, jest mimo wszystko unum idem. Dlatego należy wziąć pod uwagę istotne pytanie: Co stanie się z dziećmi i stroną, która nie akceptuje stwierdzenia nieważności? Do tej pory wszystko wydawało się oczywiste, ale niestety, tak nie jest. Dlatego czymś koniecznym jest, by za potwierdzeniem zasady szły odpowiednie postanowienia, przy czym zawsze należy pamiętać, że rodzina jest podstawą społeczeństwa i nadal jest najbardziej odpowiednią strukturą do zapewnienia osobom pełnego dobra niezbędnego do ich stałego rozwoju (Przemówienie do Europejskiej Federacji Katolickich Stowarzyszeń Rodzin, 1 czerwca 2017 roku). W związku z tym jesteśmy wezwani do określenia drogi, która prowadzi do wyborów zgodnych $\mathrm{z}$ ustalonymi zasadami. Wszyscy zdajemy sobie sprawę, jak trudne jest przejście od zasad do faktów. Kiedy mówi się o integralnym dobru osób, należy koniecznie zadać sobie pytanie, jak może się to zdarzyć w wielu sytuacjach, w których znajdują się dzieci' ${ }^{6}$.

Z kolei Ojciec Święty zwraca uwagę, że nowy związek sakramentalny, który powstaje po stwierdzeniu nieważności małżeństwa, z pewnością będzie źródłem pokoju dla małżonka, który o to poprosił. Jak jednak, pyta, wytłumaczyć dzieciom, że - na przykład ich matka, porzucona przez ich ojca i często niepragnąca zawarcia nowego małżeństwa, przyjmuje z nimi niedzielną Eucharystię, podczas gdy ojciec, mieszkając wspólnie z inną kobietą lub oczekując na stwierdzenie nieważności małżeństwa, nie możesz uczestniczyć

infatti, è sempre e comunque il frutto benedetto del patto coniugale; non può estinguersi in toto con la dichiarazione di nullità, perché non si può considerare l'essere famiglia come un bene sospeso, in quanto è frutto del progetto divino, almeno per la prole generata. I coniugi con i figli donati da Dio sono quella nuova realtà che chiamiamo famiglia”. Discorso del Santo Padre Francesco..., akapit 4.

6 TAMżE, akapit 5. 
w stole eucharystycznym? Stawiając to pytanie, Franciszek dodaje, że z okazji Nadzwyczajnego Zgromadzenia Ogólnego Synodu Biskupów w 2014 roku oraz Zgromadzenia Zwyczajnego w 2015 roku Ojcowie synodalni, gdy rozważali temat rodziny, postawili sobie te pytania, zdając sobie również sprawę z tego, że danie odpowiedzi jest trudne, czasem niemożliwe. Jednak niepokój Ojców synodalnych i macierzyńska troska Kościoła, w obliczu tak wielu cierpień, znalazły pożyteczne narzędzie duszpasterskie w Adhortacji apostolskiej Amoris laetitia. W dokumencie tym podano jasne wskazania, tak aby nikt, zwłaszcza maluczcy i cierpiący, nie był pozostawiony samemu sobie albo traktowany jako środek szantażu między podzielonymi rodzicami (Adhortacja apostolska Amoris laetitia, n. 241) ${ }^{7}$. Papież przypomina, że najbliższego 19 marca rozpocznie się „Rok Rodziny Amoris Laetitia"; niewątpliwie i sędziowie rotalni swoją pracą wnieśli cenny wkład w tę „kościelną drogę” $\mathrm{z}$ rodzinami dla rodziny ${ }^{8}$.

\section{Otwarcie sędziów na horyzonty duszpasterstwa rodzin}

W dalszym ciągu swojej alokucji Mówca zwraca się do audytorów rotalnych $z$ apelem. Pragnie mianowicie, by nie zapominali o świadczeniu o owym apostolskim niepokoju Kościoła, uważając, że integralne

\footnotetext{
7 „W niektórych przypadkach, wzięcie pod uwagę swojej godności i dobra dzieci narzuca postawienie stanowczego kresu nadmiernym roszczeniom drugiej osoby, wielkiej niesprawiedliwości, przemocy lub chronicznemu brakowi szacunku. Trzeba przyznać, że «są przypadki, w których separacja jest nieunikniona. Niekiedy może stać się wręcz z moralnego punktu widzenia konieczna, kiedy chodzi właśnie o to, by uchronić słabszego małżonka lub małe dzieci przed poważniejszymi ranami, powodowanymi przez znęcanie się i przemoc, upokorzenia i wyzysk, obcość i obojętność»”. FranciszeK, Katecheza z 24.06.2015, L'Osservatore Romano (wyd. polskie), 7-8 (2015), s. 52; „Jednak «należy ją uznać za środek ostateczny, kiedy już wszelkie rozsądne oddziaływania okażą się daremne»" (Jan Paweł II, Adhortacja apostolska „Familiaris consortio” (22.11.1981), AAS 74 (1982), s. 184)”; Francesco, „Amoris laetitia”. Esortazione apostolica sull'amore nella familia, Città del Vaticano-Cinisello Balsamo 2016. Tekst polski: Ojciec Święty Franciszek, Posynodalna Adhortacja Apostolska „Amoris laetitia”. O miłości w rodzinie, Kraków 2016, n. 241.
}

8 Discorso del Santo Padre Francesco..., akapit 6. 
dobro osoby wymaga, by nie pozostawać obojętnym w obliczu katastrofalnych skutków, jakie może pociągnąć za sobą orzeczenie o nieważności małżeństwa. Trybunał Apostolski Roty Rzymskiej, jak również inne trybunały Kościoła, prosi, aby „procedury stwierdzania przypadków nieważności małżeństw były bardziej dostępne i sprawne, a także, być może całkowicie bezpłatne" (Adhortacja apostolska Amoris laetitia, n. 244) ${ }^{9}$.

Ojciec Święty stwierdza następnie, że Kościół jest matką, a sędziowie, którzy pełnią posługę kościelną w tak istotnej dziedzinie, jaką jest działalność sądownicza, są wezwani do otwarcia się na horyzonty tego duszpasterstwa trudnego, lecz nie niemożliwego, które dotyczy troski o dzieci jako niewinne ofiary wielu sytuacji rozpadu rodzin, rozwodu lub nowych związków cywilnych (por. Adhortacja apostolska Amoris laetitia, n. 245). „Jest to kwestia wykonywania waszej misji sędziowskiej, jako posługi o charakterze duszpasterskim, której nigdy nie może zabraknąć w delikatnej decyzji o nieważności lub nie, wspólnoty małżeńskiej. Stwierdzenie nieważności małżeństwa jest często postrzegane jako zimny akt zwykłej «decyzji prawnej». Ale tak nie jest i nie może być. Wyroki sędziego kościelnego nie moga ignorować pamięci, złożonej z blasków i cieni, które naznaczyły życie nie tylko dwojga małżonków, ale także dzieci. Małżonkowie i dzieci stanowią wspólnotę osób, która jest zawsze i na pewno utożsamiana $\mathrm{z}$ dobrem rodziny, nawet gdy się rozpadła"10.

\footnotetext{
9 TAmżE, akapit 7.

10 „Si tratta di esercitare la vostra missione di giudici come un servizio carico di senso pastorale, che non può mai mancare nella delicata decisione sulla nullità o meno dell'unione coniugale. Spesso si pensa alla dichiarazione di nullità matrimoniale come a un atto freddo di mera „decisione giuridica”. Ma non è e non può essere così. Le sentenze del giudice ecclesiastico non possono prescindere dalla memoria, fatta di luci e di ombre, che hanno segnato una vita, non solo dei due coniugi ma anche dei figli. Coniugi e figli costituiscono una comunità di persone, che si identifica sempre e certamente col bene della famiglia, anche quando essa si è sgretolata". TAмżE.
} 


\section{Wyobraźnia miłości w obliczu rodzinnych tragedii}

„Nie wolno nam zmęczyć się, kontynuuje Następca Benedykta XVI, w poświęcaniu rodzinie i małżeństwu chrześcijańskiemu całej uwagi i troski: tutaj poświęcacie wielką część waszego starania o dobro Kościołów partykularnych. Niech Duch Święty, którego wzywacie przed podjęciem każdej decyzji co do prawdy o małżeństwie, oświeci was i pomoże wam nie zapomnieć o skutkach takich aktów: przede wszystkim o dobru dzieci, ich pokoju lub, przeciwnie, o utracie radości w perspektywie rozłączenia. Niech modlitwa - sędziowie powinni dużo się modlić - i wspólne zobowiązanie pozwolą uwydatnić ludzką rzeczywistość, często cierpiącą: rodzinę podzieloną i inną, która w następstwie zostaje ustanowiona, naruszając ową jedność, która uszczęśliwiała dzieci w poprzednim związku”"11.

Franciszek, jak stwierdza, „korzysta z okazji, aby zachęcić każdego biskupa - ustanowionego przez Chrystusa ojcem, pasterzem i sędzią w swoim własnym Kościele - do coraz większego otwierania się na wyzwanie związane z tą tematyką. Chodzi o wytrwałość i dokończenie koniecznej drogi eklezjologicznej i duszpasterskiej, której celem jest niepozostawianie wyłącznie interwencji władz świeckich, wiernych cierpiących z powodu nieakceptowanych i nieoczekiwanych wyroków. Wyobraźnia miłości będzie sprzyjać ewangelicznej wrażliwości w obliczu rodzinnych tragedii, których uczestnicy nie mogą być zapomniani. Czymś bardzo pilnym jest to, by współpracownicy biskupa, a zwłaszcza wikariusz sądowy, odpowiedzialni za

11 „Non dobbiamo stancarci di riservare ogni attenzione e cura alla famiglia e al matrimonio cristiano: qui voi investite gran parte della vostra sollecitudine per il bene delle Chiese particolari. Lo Spirito Santo, che invocate prima di ogni decisione da prendere sulla verità del matrimonio, vi illumini e vi aiuti a non dimenticare gli effetti di tali atti: innanzitutto il bene dei figli, la loro pace o, al contrario, la perdita della gioia davanti alla separazione. Possano la preghiera - i giudici devono pregare tanto! - e l'impegno comune porre in risalto questa realtà umana, spesso sofferente: una famiglia che si divide e un'altra che, di conseguenza, viene costituita pregiudicando quell'unità che faceva la gioia dei figli nella precedente unione". TAMżE, akapit 8 . 
duszpasterstwo rodzin, a przede wszystkim proboszczowie, starali się realizować tę diakonię ochrony, troski i towarzyszenia małżonkowi opuszczonemu i ewentualnie dzieciom, którzy muszą ponosić konsekwencje decyzji, choć słusznych i prawowitych, o nieważności małżeństwa"12.

\section{Uznanie dla Trybunału Roty Rzymskiej}

W podsumowaniu Ojciec Święty oznajmia, że jest przekonany, iż kwestie, na które musiał zwrócić uwagę, znajdą u adresatów alokucji zrozumienie i gotowość uczynienia ich własnymi. Wyraża przy tym każdemu uznanie w nadziei, że Trybunał Roty Rzymskiej, autorytatywny przejaw prawniczej mądrości Kościoła, będzie nadal konsekwentnie wykonywał swój niełatwy munus w służbie Bożego planu w stosunku do małżeństwa i rodziny. Przywołując zaś dary Ducha Świętego nad Audytorami rotalnymi i pozostałymi pracownikami wymienionego Trybunału oraz nad ich pracą, zapowiada, iż za chwilę z serca udzieli swojego apostolskiego błogosławieństwa i prosi o modlitwę w swojej intencji ${ }^{13}$.

\footnotetext{
12 „Colgo questa occasione per esortare ogni Vescovo - costituito da Cristo padre, pastore e giudice nella propria Chiesa - ad aprirsi sempre più alla sfida legata a questa tematica. Si tratta di proseguire con tenacia e portare a compimento un necessario cammino ecclesiologico e pastorale, volto a non lasciare al solo intervento delle autorità civili i fedeli sofferenti per giudizi non accettati e subiti. La fantasia della carità favorirà la sensibilità evangelica di fronte alle tragedie familiari i cui protagonisti non possono essere dimenticati. È quanto mai urgente che i collaboratori del Vescovo, in particolare il vicario giudiziale, gli operatori della pastorale familiare e soprattutto i parroci, si sforzino di esercitare quella diaconia di tutela, cura e accompagnamento del coniuge abbandonato ed eventualmente dei figli, che subiscono le decisioni, seppur giuste e legittime, di nullità matrimoniale”. TAMżE. 13 TAмżE, akapit 9.
} 


\section{Podziękowanie dla dziekana Pio Vito Pinto}

Ta zapowiedź błogosławieństwa papieskiego została spowodowana okolicznością kontynuowania alokucji w jej finalnym wątku, na co wskazał sam Mówca: „I nie chciałbym dzisiaj kończyć bez odniesienia bardziej rodzinnego, między nami, ponieważ nasz drogi Dziekan za kilka miesięcy osiągnie młodość 80. lat i będzie musiał nas opuścić. Chciałbym mu podziękować za wykonaną pracę, nie zawsze rozumianą. Przede wszystkim chciałbym podziękować Mons. Pinto za ową wytrwałość, jaką okazał w dokonaniu reformy procesów małżeńskich: tylko jeden wyrok, potem proces skrócony, co było jakby nowością, lecz było to czymś naturalnym, gdyż biskup jest sędzią"14.

„Pamiętam, kontynuuje Papież Argentyńczyk, że wkrótce po promulgacji owego procesu skróconego zadzwonił do mnie pewien biskup i powiedział: «Mam ten problem: pewna dziewczyna chce wyjść za mąż w Kościele; wyszła już za mąż kilka lat temu w Kościele, ale została zmuszona do zawarcia małżeństwa, ponieważ była w ciąży... Uczyniłem wszystko, poprosiłem księdza, który był wikariuszem sądowym, innego, który był obrońcą węzła małżeńskiego... A świadkowie, rodzice mówią, że tak, została zmuszona, że to małżeństwo było nieważne. Powiedz mi, Świątobliwość, co powinienem zrobić?», zapytał mnie biskup. Ja go zapytałem: «Powiedz mi, czy masz pod ręką pióro?» - «Tak» - «Podpisz. Jesteś sędzią, bez takich historii»"15.

\footnotetext{
14 „E non vorrei finire oggi senza un commento più familiare, tra noi, perché il nostro caro Decano avrà, fra alcuni mesi, la giovinezza di 80 anni, e dovrà lasciarci. Io vorrei ringraziarlo, per il lavoro fatto, non sempre compreso. Soprattutto, vorrei ringraziare Mons. Pinto per quella tenacia che ha avuto per portare avanti la riforma dei processi matrimoniali: una sola sentenza, poi il processo breve, che è stato come una novità, ma era naturale perché il vescovo è il giudice”. TAMżE, akapit 10 .

15 „Ricordo che, poco tempo dopo la promulgazione del processo breve, mi chiamò un vescovo e mi disse: «Io ho questo problema: una ragazza vuole sposarsi in Chiesa; si è già sposata alcuni anni fa in Chiesa, ma è stata costretta a sposarsi perché era incinta... Ho fatto tutto, ho chiesto a un prete che facesse da vicario giudiziale, un altro che facesse la parte di difensore del vincolo... E i testimoni, i genitori dicono che sì, è stata forzata, che quel matrimonio era nullo. Mi dica, Santità, cosa devo
} 
„Ale ta reforma, kontynuuje Papież, przede wszystkim proces skrócony, napotkała i nadal napotyka duży opór. Wyznaję wam: po tej promulgacji otrzymałem listy, wiele, nie wiem ile, ale wiele. Niemal wszyscy adwokaci tracili klientów. I tutaj tkwi problem pieniędzy. W Hiszpanii mówi się: «Za pieniądze tańczy małpa» (Por la plata baila el mono). Powiedzenie to jest jasne. I to też powiem z żalem: widziałem w niektórych diecezjach opór niektórych wikariuszy sądowych, którzy tą reformą stracili, nie wiem, pewną władzę, ponieważ zdali sobie sprawę, że sędzią nie jest on sam, ale biskup"16.

Następnie papież Franciszek podziękował Mons. Pio Vito Pinto za odwagę, którą się wykazał, a także za strategię podążania za tym sposobem myślenia i oceniania, aż do jednomyślności w opiniowaniu, co stworzyło mu możliwość podpisania dokumentu ${ }^{17}$.

Nawiązując z kolei do zniesienia zasady „dwóch wyroków zgodnych”, Ojciec Święty stwierdza, że Mons. Pinto (w swoim przemówieniu) wymienił papieża Lambertiniego (późniejszy Benedykt XIV, które tę zasadę wprowadził), wielkiego znawcę liturgii, prawa kanonicznego, pełnego zdrowego rozsądku, a nawet poczucia humoru, ale niestety, musiał on wprowadzić zasadę doppia sentenza z uwagi na problemy ekonomiczne w niektórych diecezjach.

„Ale wróćmy do prawdy, stwierdza następnie Mówca oznajmiając, że sędzią jest biskup. Jest wspierany przez wikariusza sądowego, jest wspierany przez rzecznika sprawiedliwości, jest wspierany, lecz on

fare?», mi domandò il vescovo. E io chiesi: «Dimmi, hai una penna a portata di mano?» - «Sì» - «Firma. Tu sei il giudice, senza tante storie»". TAMżE, akapit 11.

16 „Ma questa riforma, soprattutto il processo breve, ha avuto e ha tante resistenze. Io vi confesso: dopo questa promulgazione ho ricevuto lettere, tante, non so quante ma tante. Quasi tutti avvocati che perdevano la clientela. E lì c'è il problema dei soldi. In Spagna si dice: «Por la plata baila el mono: per i soldi balla la scimmietta». E un detto che è chiaro. E anche questo con dolore: ho visto in alcune diocesi la resistenza di qualche vicario giudiziale che con questa riforma perdeva, non so, un certo potere, perché si accorgeva che il giudice non era lui, ma il vescovo". TAмżE, akapit 12 .

17 TAMŻE, akapit 13. 
jest sędzią, nie może od tego umyć sobie rąk. [Należy] powracać do tego, co jest prawdą ewangeliczną"18.

Franciszek kończy, dziękując dziekanowi Pinto także za jego entuzjazm w nauczaniu katechezy na ten temat. „Podróżuje po świecie, ucząc tego. Jest człowiekiem entuzjastycznym, ale entuzjastycznym we wszystkich «tonach», ponieważ również on ma taki «charakterek»! To negatywny sposób, by tak powiedzieć, entuzjazmu. Ale będzie miał czas, żeby się poprawić..., wszyscy go mamy! Chciałbym mu podziękować! Oklaski interpretuję jako aplauz dla "charakterku». Dziękuję bardzo, Mons. Pinto! Grazie!”19.

\section{Uwagi końcowe}

Kolejna, już ósma, alokucja papieża Franciszka wygłoszona do Roty Rzymskiej została poświęcona kilku wątkom tematycznym związanym $\mathrm{z}$ orzekaniem $\mathrm{w}$ sprawach nullitatis matrimonii; przebija $\mathrm{z}$ niej głęboka troska o rodzinę. Instytucja ta, będąca podstawową komórką życia społecznego, wyrastająca na gruncie małżeństwa, nie przestaje pozostawać - od samego początku - w orbicie szczególnych zainteresowań Papieża, o czym wymownie świadczy obszerna i bogata w treść jego posynodalna Adhortacja apostolska Amoris laetitia z 19 marca 2016 roku. Dokument ten sam autor określił jako „propozycję dla chrześcijańskich rodzin, która budzi je do doceniania darów małżeństwa i rodziny oraz do podtrzymania miłości silnej i pełnej takich wartości, jak wielkoduszność, zaangażowanie, wierność i cierpliwość" 20 .

Koncentrując w swoim przemówieniu „rotalnym” uwagę na „dobru rodziny”, Ojciec Święty podkreśla, że choć owo bonum familiae nie utorowało sobie drogi do rangi nowego tytułu nieważności małżeństwa (nie miało na to „żadnych szans”, mimo podejmowanych

\footnotetext{
18 TAMŻE, akapit 14.

19 TAMŻE, akapit 15.

20 Ojciec Święty Franciszek, Posynodalna Adhortacja Apostolska „Amoris laetitia”. O miłości $w$ rodzinie, n. 5.
} 
w tym zakresie prób), to jednak należy je uznać za niekwestionowaną rzeczywistość obejmującą małżonków i dzieci, stanowiącą owoc planu Bożego.

W tym właśnie kontekście Franciszek podejmuje istotny wątek złożonych skutków orzeczenia nieważności małżeństwa. Trafnie zauważa, że gdy strona powodowa jest zawsze w pełni usatysfakcjonowana pozytywnym rozstrzygnięciem prowadzonej sprawy, to nie zawsze satysfakcję tę podziela strona pozwana, pozostając - często z dziećmi (o tym, oczywiście, decyduje Trybunał państwowy) - w szczególnej sytuacji. Zasadny więc wydaje się niepokój Ojca Świętego, gdy pyta: „Co stanie się z dziećmi i stroną, która nie akceptuje stwierdzenia nieważności?” i czy można wówczas mówić o „integralnym dobru osób?”. Ten niepokój dotyczy także aspektu życia sakramentalnego rozwiedzionych małżonków, gdy jedna ze stron, trwając w nowym (niekanonicznym) związku małżeńskim, nie może przystąpić do Komunii św.

W pełni zrozumiały jest apel papieża Bergoglio skierowany do sędziów rotalnych oraz sędziów wszystkich trybunałów kościelnych, by dzielili ów niepokój Kościoła, zdając sobie sprawę z „katastrofalnych” skutków, jakie może wywołać - w niejednym przypadku - orzeczenie opatrzone końcową sentencją „constare de nullitate”. Powinni więc okazywać troskę o dzieci jako ofiary rozpadu rodzin, włączając się w nurt duszpasterstwa rodzin. Przypominają się wymowne słowa Franciszka z Adhortacji apostolskiej Amoris laetitia: „Dlatego wspólnoty chrześcijańskie nie powinny pozostawiać samym sobie rozwiedzionych rodziców żyjących w nowych związkach. Wręcz przeciwnie, powinny ich włączać i towarzyszyć im w ich roli wychowawczej"21.

Wzmiankę - w tym kontekście - o potrzebie łatwiejszej dostępności do procedur małżeńskich oraz ich większej sprawności, a także o ich darmowości („być może”) należy rozumieć jako zachętę do ułatwiania zainteresowanym małżonkom możliwości uregulowania w sądzie kościelnym własnych spraw z zakresu stanu cywilnego.

21 TAMŻE, n. 246. 
Na uwagę zasługuje dyrektywa papieska, w myśl której orzeczenia trybunałów kościelnych nie powinny być „zimnymi aktami” natury prawnej, mają bowiem wyrażać także pamięć „złożoną z blasków i cieni”, które znamionowały życie nie tylko małżonków, ale i dzieci ${ }^{22}$. Wynika stąd, że w orzeczeniu stwierdzającym nieważność małżeństwa należałoby poczynić wzmiankę o dzieciach (w formie przypomnienia o naturalnym obowiązku troski o ich wychowanie). Cenna jest sugestia skłaniająca sędziów kościelnych do modlitwy poprzedzającej podjęcie decyzji w danej sprawie (można „dopowiedzieć": np. podczas sesji przedwyrokowej).

Troskliwość Franciszka o losy rodziny nakazała mu skierować swoją myśl ku biskupom diecezjalnym jako pierwszym sędziom we własnych Kościołach partykularnych. To właśnie oni powinni inspirować swoich wikariuszy sądowych, liderów duszpasterstwa rodzin, a nade wszystko proboszczów, do ofiarnego podejmowania ochrony, troski i towarzyszenia małżonkowi opuszczonemu i ewentualnie dzieciom, którzy muszą ponosić konsekwencje pozytywnych orzeczeń kościelnych w sprawach małżeńskich. Apel ten w pełni odpowiada następującemu fragmentowi Adhortacji apostolskiej Amoris laetitia: „Rozwód jest złem i bardzo niepokojący jest wzrost liczby rozwodów. $Z$ tego względu niewątpliwie naszym najważniejszym zadaniem duszpasterskim w odniesieniu do rodzin jest umocnienie miłości i pomaganie w leczeniu ran, abyśmy mogli zapobiec poszerzaniu się tego dramatu naszych czasów"23.

W nawiązaniu do wspomnianej wyżej zachęty Papieża, by nie pozostawać obojętnym w obliczu „katastrofalnych” skutków, jakie może pociągnąć za sobą orzeczenie o nieważności małżeństwa, należy zdecydowanie przyjąć, iż temuż Biskupowi Rzymskiemu nie

\footnotetext{
$22 \mathrm{~W}$ jednym $\mathrm{z}$ wyroków stwierdzających nieważność małżeństwa $\mathrm{z}$ tytułu wykluczenia przez powoda nierozerwalności, w odpowiedzi na uwagi obrońcy węzła małżeńskiego, iż obydwie strony (a więc i powód) starannie wychowywały dzieci, ponens stwierdził, że sprawa dzieci, sędziów „nie interesowała”.

${ }^{23}$ Ojciec Święty Franciszek, Posynodalna Adhortacja Apostolska „Amoris laetitia”. O miłości w rodzinie, n. 246.
} 
można przypisać intencji sugerowania pewnej wstrzemięźliwości w ferowaniu orzeczeń pro nullitate. Gdy bowiem w danej sprawie sędziowie (w trybunałach jednoosobowych sędzia) dysponują odpowiednimi dowodami na rzecz nieważności małżeństwa (i mają co do tego pewność moralną), żaden wzgląd na dzieci pochodzące z tego związku nie może ich powstrzymać od wydania wyroku pozytywnego. Ojcu Świętemu chodziło jedynie o to, by zasygnalizować problem szczególnie dotkliwej sytuacji małżonków, którzy zostali porzuceni, i których nie satysfakcjonuje pozytywne rozstrzygnięcie sądu kościelnego w sprawie rozpoznanej z powództwa drugiej strony, a także podobnej sytuacji dzieci pochodzących z takich małżeństw.

Warto zauważyć, że podobna sytuacja może mieć miejsce również w przypadku zapadnięcia wyroku negatywnego w sprawie o nieważność małżeństwa. Źródłem niepokoju o los małżonka porzuconego i dzieci jest faktyczne rozbicie rodziny, niezależnie od takiego czy innego werdyktu trybunału kościelnego.

Niemal w każdej alokucji papieskiej wygłaszanej na rozpoczęcie nowego roku sądowego mówca wyraża uznanie dla niełatwej posługi audytorów Roty Rzymskiej. Nie mogło tego wątku zabraknąć i w przemówieniu Franciszka z 2021 roku. Określenie efektów pracy wymienionego Trybunału mianem „autorytatywnego przejawu prawniczej mądrości Kościoła” było niewątpliwie wyrazem takiego uznania.

Doceniając też osobisty wkład w funkcjonowanie i aktywność orzeczniczą Roty Rzymskiej bliskiego emerytury, bez mała osiemdziesięcioletniego jej dziekana (od 2012 roku), Mons. Pio Vito Pinto, Ojciec Święty nie omieszkał serdecznie i z właściwym sobie poczuciem humoru podziękować mu za trud związany z pełnieniem tak angażującej funkcji. Jednocześnie dał do zrozumienia, jak wiodąca była jego rola w przeprowadzeniu w 2016 roku reformy procesu małżeńskiego.

Kolejne przemówienie Franciszka do Roty Rzymskiej z pewnością przyczyni się do bardziej duszpasterskiego otwarcia się nie tylko audytorów rotalnych, ale też całej rzeszy sędziów kościelnych pełniących swoją posługę w trybunałach niższych instancji, a ponadto biskupów, proboszczów i innych duszpasterzy. W szczególności otwarcie to 
będzie ukierunkowane ku małżonkom i ich dzieciom, którzy padli ofiarą rozbicia rodziny.

\section{References}

Benedictus XVI, Discorso per l'apertura del Sinodo dei Vescovi del 7 ottobre 2012, http://www.vatican/content/benedict-XVI/it/homilis/29121007_apertura-sinodo-html (dostęp 2.02.2021).

Benedictus XVI, Discorso al Clero della diocesi di Aosta del 25 luglio 2005, AAS 97 (2005), s. 168-172;

Benedictus XVI, Discorso alla Rota Romana del 26 gennaio 2013, AAS 105 (2013), s. 168-172;

Discorso del Santo Padre Francesco agli Officiali del Tribunale della Rota Romana, per l'inaugurazione dell'Anno Giudiziario (29.01.2021), https://www.vatican.va/content/francesco/en/speeches/2021/january/documents/papa-francesco_20210129_ rota-romana.html

FrANCESCO, „Amoris laetitia”. Esortazione apostolica sull'amore nella familia, Città del Vaticano-Cinisello Balsamo 2016. Tekst polski: OjCiec Święty Franciszek, Posynodalna Adhortacja Apostolska „Amoris laetitia”. O miłości w rodzinie, Kraków 2016.

FranciszeK, Katecheza z 24.06.2015, L’Osservatore Romano (wyd. polskie), 7-8 (2015).

GóRALSKI W., Małżonkowie chrześcijańscy na wzór Akwili i Pryscylli darem Bożym i potrzeba Kościoła. Z przemówienia Franciszka do Roty Rzymskiej z 25 stycznia 2020 roku, Prawo Kanoniczne (w druku).

Serrano Ruiz J.M., Familia e pluralismo religioso: Note introduttive. Presupposti e prospettive nel sistema Canonico, w: Tutela della famiglia e diritto dei minori nel Codice di Diritto Canonico, Città del Vaticano 2000.

Serrano Ruiz J.M., Il "bonum coniugum" e la dottrina tradizionale dei "bona matrimonii”, w: Il „bonum coniugum" nel matrimonio canonico, Città del Vaticano 1996.

Serrano Ruiz J.M., L'esclusione della prole e la sua assolutezza: il problema della paternità responsabile, w: Prole e matrimonio canonico, Città del Vaticano 2003.

\section{Nota o autorze}

Ks. Wojciech Góralski - profesor zwyczajny, kierownik Zakładu Prawa Rodzinnego na Wydziale Prawa Kanonicznego UKSW, założyciel i pierwszy redaktor naczelny kwartalnika „Ius Matrimoniale”, wiceprzewodniczący Stowarzyszenia Kanonistów Polskich, sędzia w Sądzie Biskupim w Płocku. 